\title{
Study on the Guidance of Fashion Culture in College Students' Ideological and Political Education
}

\author{
Qing He
}

Weinan Normal University, Weinan, Shaanxi, 714000

\author{
Keywords: Fashion Culture, Ideological and Political Education, College Students, College Culture
}

\begin{abstract}
With the continuous development of science and technology, especially with the rapid development of information technology, fashion culture has penetrated into people's daily life more and more deeply and has a direct impact on people's thoughts and behaviors. As a pioneer and behavioral avant-garde young college students, college students become the main body of fashion culture practice. With their keen feelings and active thinking, college students enhance the awareness of fashion culture, and colleges and universities become fashion culture Important position. However, the influences of fashion culture have both advantages and disadvantages. As the ideological and political education that guides the formation and development of college students' outlook on life, values and world outlook, how to avoid the unfavorable influence of fashion culture and exert its beneficial influence, make the ideological and political education of college students adapt better Development needs of the times. Based on the analysis of the connotation of fashion culture, the article analyzes the pros and cons of fashion culture influence and puts forward the strategy of guiding students to correctly view the fashion culture.
\end{abstract}

\section{Introduction}

The so-called fashion is a social life in a particular period or a group of a wide range of social life style, mainly through clothing, decoration, transportation, construction, hobby, individual and other performance, which is essentially a Population groups of psychological state. Because of its belonging to a group of state of mind, so it has the characteristics of both followers and personalized pursuit, which is not only an overall reflection of various fashion phenomena, but also a unique social subcultures, both human civilization Evolving progress, but also the fashion content and form the perfect result of development. Specifically, the characteristics of fashion culture mainly in the following areas:

First, entertaining and avant-garde. While the traditional culture is characterized by serious and orthodox character, the fashion culture emphasizes individuality, fashion, relaxation and entertaining. In particular, its traditional carrier is dominated by television and the Internet, so its entertaining features are more prominent. Under the social context of multicultural coexistence, fashion culture has become an unique symbol with its exaggeration and uniqueness. Second, spread and transient. Only through the continuous expansion and spread of fashion culture can be spread into the true sense of the fashion culture, but the prevalence of fashion culture usually stay for a relatively short period of time, will continue to have updated fashion elements replaced. Again, class and popularity. Fashion and more through the popular form of simple expressions of emotion and philosophy, which reflects the characteristics of the popular. Such as network spoof shows a deconstruction of tradition, publicity personality, satirical social rebellious spirit, reflecting the characteristics of civilians, grassroots. Finally, commercial and consumer. Consumption and fashion are two phenomena which are inseparable. With the development of economy and more relaxed cultural environment, the liberation of mass media has created favorable conditions for the formation and development of fashion culture. Therefore, the fashion culture and the consumption of commodities gradually establish a close Indispensable relationship. 


\section{The impact of fashion culture on college students thinking}

The influence of fashion culture on college students' thinking has two advantages and disadvantages:

Specifically, the positive impact of fashion culture on college students in the following areas: First, to stimulate students' sense of innovation. Mentioned above, the fashion culture embodies avant-garde, commercial, consumer characteristics, its development and the development of the times are closely related to fashion and traditional culture of thinking is completely different mode of thinking out of the shackles of thinking, college students follow the fashion culture The flexible use of aggregate thinking, reverse thinking, divergent thinking so that more changes in their own lives, to accept more cutting-edge information, fashion culture can continue to inspire the sense of innovation of college students to maintain their vitality of thinking. Second, publicize the personality of college students. Modern college students enjoy the fruits of reform and opening up. They continue to accept more fashion culture such as computers, cartoons, televisions, hamburgers and so on during the growth process. For fashion students, these fashionable elements are the best expression of their individuality Way, so through popular language, fashion style, a variety of symbols and symbols as a carrier of their own personality. Finally, to alleviate the mental stress of college students. In addition to daily course study, skills training and essay writing, as well as complicated social relations such as relationships, frustration in love and employment competition, the mental pressure of college students is very intense. relatively bigger. The songs, clubbing, $\mathrm{K}$ songs, hip-hop and other fashion and cultural activities can enrich the spiritual life of college students, to some extent, to alleviate the pressure of their mental.

Everything has two sides, the influence of fashion culture on college students' thoughts and minds also has two sides, and its negative effects are mainly reflected in the following aspects:

First of all, it leads to the chaos of college students' values. Fashion culture emphasizes individuality and unconventional ideas. For undergraduates who are inexperienced, if they can not correctly understand the fashion elements, they will distort their correct values and weaken their collectivism consciousness to a certain extent. For example, some students are addicted to the virtual world of online games and are gradually separated from their collective life. Still others have conflicting with the school rules and regulations and social moral constraints, forming values such as personal supremacy. These are not conducive to social stability and harmonious development. Second, lead to the vulgarization of college students aesthetic taste. Fashionable culture reflects its unique personality. However, it is only separated from the labels such as "alternative" and "weirdness." Although it can meet the psychological demands of college students, they are inevitably driven by commercial interests There are shallow, vulgar features, if there is aesthetic deviation of college students, they will think that fashion is ugly, weird things, leading to vulgar vulgarization of its aesthetic taste. Finally, weakened the bad fashion culture on the moral judgment of college students. The main purpose of ideological and political education is to guide college students to distinguish right and wrong and to show their righteousness and goodness. However, ideological and political education at the present stage is not only serious in content but also rigid in form. Students are poorly motivated in education and even have some resistance. Fashion culture is everywhere advertised distinctive and unconventional, he makes people get rid of the traditional ethical standard of living, so college students are more willing to tend to such a relaxed, entertaining culture. With the virtuality and concealment of the network, some college students ignore the moral norms in order to pursue pure sensory stimulation, thus affecting their moral judgment, ultimately lowering their moral standards and losing their sense of responsibility, which seriously affect the social harmony, steady development.

\section{Guide students to correctly view the fashion culture strategy}

In view of the negative impact of fashion culture on college students, it is suggested to guide college students to correctly view and accept the fashion culture in the following aspects to 
strengthen the correct and positive influence of fashion culture:

The opening of campus culture makes a variety of social new trends, fashion culture gradually into the university campus, imperceptibly affect students' outlook on life, values, worldview. Therefore, the ideological and political education in colleges and universities should emphasize the important role of the mainstream ideology and culture. Regardless of the cultural trend of thought it should always adhere to the dominant position of traditional culture. Traditional Chinese culture has a long history and profound significance. It has become stable in the long-term development of multiculturalism. It involves literature, art, religion, custom, etiquette, education, science and so on. It is an element of various ideological and cultural traditions in the history of the Chinese nation Overall characterization, to some extent, mainstream culture is a human culture, which contains a wealth of philosophy. Cultivating qualified college students should guide them to behave in the same way. The essence of traditional culture and ideological and political education in colleges and universities is the same. Ideological and political education should make full use of the historical heritage of traditional culture, making the mainstream culture always occupy the ideological and political education in the high ground, promote the theme of society, advocate the advanced nature of fashion culture, make it serve school education. Of course, the construction of campus culture should also dare to innovate, advancing with the trend of integration of fashion elements, in the new era and new context to promote traditional culture, to attract more students not only to accept the fashion culture, but also love traditional culture.

Ideological and political culture and fashion culture are symbiotic coexistence in the modern cultural atmosphere. Modern ideological and political education should reflect on the fashion culture and make improvements: First, it examines the discourse system of ideological and political education under the influence of fashion culture. Ideological and political education should be based on the reality, the fashion characters, fashion language, fashion and cultural style and philosophical thinking and ideological and political education together, the establishment of appropriate communication context of discourse, to abandon the vulgar elements of fashion culture, to avoid its Distortion of student values. Secondly, we review the ideological and political education in the influence of fashion culture, strengthen the education of students 'media literacy, enhance the students' use of media resources to improve themselves and improve their ability of judgment and comprehension. Guide students based on the actual needs of their own development of fashion culture to crude and refined. Finally, using the visual image of fashion culture as a guide element, guiding students to understand and internalize the theory of ideology and politics, infiltrating the ideological and political education into the fashion culture through penetrating, cultivating and practicing experiential methods, Centripetal force, charisma to give full play to improve the ideological and moral quality of college students.

No matter what kind of fashion culture, we must penetrate the human society through certain cultural markets and media, but under the influence of the market and the media, by the interests of some of the vulgar fashion culture will be spread to college students, college students Values have a negative impact. Therefore, it is necessary to strengthen the supervision and management of campus culture and provide a more reliable guarantee for the survival and development of the campus fashion culture. First of all, through the government and social forces, we can step up supervision and management of the market and the media, strengthen restraints from the legal and institutional levels, clean up the market for fashion culture, standardize its dissemination, increase filtering of bad information through advanced technologies, and reduce vulgarity, The content of low-grade circulation. Second, to promote the production of fashion culture to meet the requirements of the law, in line with the requirements of advanced culture, in line with the cultural needs of college students. Finally, as media of all kinds of fashion culture, all media and cultural workers should strictly abide by their own professional ethics, do not over-render kitsch culture and anti-mainstream culture, and provide better development and living space for a healthy fashion culture. 


\section{Conclusion}

In short, to a certain extent, the fashion culture of college students, regardless of any form of discipline their essence is to use college students to build a new self-identity mentality, traditional culture weakened the normative power of students, bright and beautiful The fashion culture involves industrial production, technical rationality, a variety of factors will play a disciplinary role in college students and enhance self-identity of college students. However, this self-identity is based on the illusory value system of symbols. Therefore, it is necessary to strengthen the correct guidance of college students to form a correct and positive understanding of fashion culture. The teacher should analyze the campus fashion culture in a correct and in-depth manner and guide students to pursue a more positive and healthy fashion culture through words and deeds, helping them to establish positive values, world outlook and outlook on life.

\section{References}

[1] Liu Tieying. The double impact of fashion culture on college students' values in the new period [J]. New Curriculum Research (Higher Education), 2017 (5): 36

[2] Wang Qiumei. Zhang Jiansheng. Fashion culture in the campus reflects and role [J] Lanzhou Academic Journal, 2017 (4) .16

[3] Chi Yongchi. On fashion culture and ideological and political education of college students [J]. Shanxi Youth Cadres College, 2016,32 (4): 35-37.

[4] Ren Xiangbao. Studies on the status quo of college fashion culture and its impact on the values of college students [J]. China Power Education, 2016,2 (18): 31.

[5] Liu Guanjun. On China's contemporary fashion culture development and correct guidance [J]. Scientific Socialism, 2016,68 (4): 32-34.

[6] Li Lixia. On the negative impact of fashion culture on college students' values and countermeasures [J]. Yangzhou University, 2014,12 (2): 72-75. 